\title{
A Value Chain Approach to Support Southeast Asia Economic Regionalism
}

\author{
Craig A. M. Jones
}

Argosy University, Hawaii

\begin{abstract}
This article includes an exploration of the economic data sets of the Association of Southeast Asian Nations (ASEAN) Statistics, the World Bank, and the International Monetary Fund, as well as primary regional economic initiatives and agreements to assess the strategic indicators of economic regionalism using thematic analysis. The aim of this research is to determine how Southeast Asian regionalism can circumvent vulnerabilities to another economic crisis in North America and the European Union. To correct such financial vulnerabilities, ASEAN has significantly remolded the region into a single market consisting of a 10-nation integrated production base. The ASEAN Economic Community's main pillars are the establishment of a regional economic foundation based on comprehensive investment initiatives; the liberalization of capital markets, tariffs, and professional labor; infrastructure connectivity; regional policy integration; and free trade agreements to create a regional value chain as part of a single market and production base. The more attainable this comprehensive value-capture-andintegration process becomes, the more attractive it will appear to the global economic investment community and for business opportunities to establish a robust regional foundation. Although the process appears straightforward, capturing value is not a single phenomenon or method, but rather a multifaceted phenomenon, as explored in this study. The regional integration model seeks profitability within effective cross-border production networks and regional liberalization.
\end{abstract}

Key words: regional economic integration, multilateral trade agreements, ASEAN single market, capital liberalization

\section{Introduction}

In a determined effort to counter the disastrous economic damage wrought by the 1997 Asian financial crisis and the 2008 global financial crisis, Asian countries collaboratively constructed comprehensive financial and economic bulwarks to protect themselves from similar future catastrophes (Das, 2012; Erkens, Hung, \& Matos, 2012; Jones, 2016;
Reinhart \& Rogoff, 2013). The ASEAN socioeconomic alliance, which consists of Brunei, Cambodia, Indonesia, Laos, Malaysia, Myanmar, Philippines, Singapore, Thailand, and Vietnam, has been a central player in a protection construction project.

All Asian nations that critically suffered from the 1997 and 2008 crises studied them and reflected on their 
imprudent and costly interactions with the powerful International Monetary Fund. ASEAN nations have drawn new financial wisdom from past misguided securitization activities with asset-backed securities concerning unbiased credit ratings and undervalued assets. Proactively, ASEAN stakeholders developed the Chiang Mai Initiative (CMI) and the Asian Bond Market Initiative (ABMI) to amass more foreign exchange reserves to act as ASEAN's own savings account to handle its future financial problems internally. ASEAN stakeholders also sought better vetted, fair foreign direct investment (FDI) at the same time. These cumulative initiatives reinforce and strengthen current efforts to develop the ASEAN Economic Community to combat regional inequality between ASEAN member states such as Cambodia, Laos, Myanmar, and Vietnam (CLMV) versus Indonesia, Malaysia, Singapore, and Thailand by focusing on financial development and economic regionalism within the boundaries of ASEAN.

The 10-nation ASEAN approach to economic regionalism constitutes a targeted multilateral methodology that involves employing a rapidly growing electronic/digital collaborative trade facilitation infrastructure to integrate itself into a single trading bloc to prevent past mistakes of high-interest borrowing, extended credit, insufficient financial liquidity, and overvalued asset-backed securities (Jones, 2016). The biggest building block for this protective shield is the CMI, created in 2000, which consists of USD 120 billion that is available for regional liquidity relief as an emergency safety tool to use in a currency or liquidity crisis within any ASEAN member state (Capannelli, 2011a, 2011b; Chin, 2012, 2014). The goal is to reduce the vulnerability of ASEAN member states to foreign financial opportunistic entities that would conspire to exploit an ASEAN member state in a weak financial position. The CMI is highly structured to fund itself and help its regional members. Table 1 shows how participating countries of the CMI contribute capital to the regional trust fund, the borrowing arrangements, and the voting power directly correlated to financial contributions (Capannelli, 2011a, 2011b).

\section{Objective and Methodology}

The objective of this research is to explore ASEAN's value chain approach to establishing an integrated regional economic framework that inoculates it against the effects of unexpected internal and external financial crises. Analyzing the regional single market model entailed deductive scrutiny of economic data sets from ASEAN Statistics, the World Bank, and the International Monetary Fund and data regarding regional economic initiatives and agreements. The research looked for real economic growth markers, primarily using the thematic analysis methodology and subsequently predictive analytics (data modeling) by exploring two important variables. The first variable is the impact of the ongoing ASEAN regional economic integration activities based on trending data from the data sets mentioned above, corresponding 
Table 1. The multilateral Chiang Mai Initiative

\begin{tabular}{|c|c|c|c|c|c|c|c|c|}
\hline \multirow[b]{2}{*}{ Members } & \multicolumn{2}{|c|}{$\begin{array}{c}\text { Financial } \\
\text { contributions }\end{array}$} & \multicolumn{2}{|c|}{$\begin{array}{c}\text { Borrowing } \\
\text { arrangements }\end{array}$} & \multicolumn{4}{|c|}{ Voting power } \\
\hline & $\begin{array}{c}\$ \\
\text { billion }\end{array}$ & $\begin{array}{c}\% \\
\text { share }\end{array}$ & Multiplier & $\begin{array}{c}\text { Quota } \\
\text { (\$ billion) }\end{array}$ & $\begin{array}{l}\text { No. of } \\
\text { basic } \\
\text { votes }\end{array}$ & $\begin{array}{c}\text { No. of votes } \\
\text { based on } \\
\text { contributions }\end{array}$ & $\begin{array}{l}\text { Total no. } \\
\text { votes }\end{array}$ & $\begin{array}{c}\% \\
\text { share }\end{array}$ \\
\hline China & 38.40 & 32.00 & & & & & 40.00 & 28.51 \\
\hline $\begin{array}{l}\text { - People's Republic } \\
\text { of China }\end{array}$ & 34.40 & 28.50 & 0.50 & 17.10 & 1.60 & 34.20 & 35.80 & 25.43 \\
\hline - Hong Kong & 4.20 & 3.50 & 2.50 & 10.50 & 0.00 & 4.20 & 4.20 & 2.98 \\
\hline Japan & 38.40 & 32.00 & 0.50 & 19.20 & 1.60 & 38.40 & 40.00 & 28.41 \\
\hline Republic of Korea & 19.20 & 16.00 & 1.00 & 19.20 & 1.60 & 19.20 & 20.80 & 14.77 \\
\hline +3 Countries & 96.00 & 80.00 & & & 4.80 & 96.00 & 100.80 & 71.59 \\
\hline Brunei Darussalam & 0.03 & 0.03 & 5.00 & 0.20 & 1.60 & 0.03 & 1.63 & 1.16 \\
\hline Cambodia & 0.12 & 0.10 & 5.00 & 0.60 & 1.60 & 0.12 & 1.72 & 1.22 \\
\hline Indonesia & 4.55 & 3.79 & 2.50 & 11.36 & 1.60 & 4.55 & 6.15 & 4.37 \\
\hline Laos & 0.03 & 0.03 & 5.00 & 0.20 & 1.60 & 0.03 & 1.63 & 1.16 \\
\hline Malaysia & 4.55 & 3.79 & 2.50 & 11.36 & 1.60 & 4.55 & 6.15 & 4.37 \\
\hline Myanmar & 0.06 & 0.05 & 5.00 & 0.30 & 1.60 & 0.06 & 1.66 & 1.18 \\
\hline Philippines & 4.55 & 3.79 & 2.50 & 11.36 & 1.60 & 4.55 & 6.15 & 4.37 \\
\hline Singapore & 4.55 & 3.79 & 2.50 & 11.36 & 1.60 & 4.55 & 6.15 & 4.37 \\
\hline Thailand & 4.55 & 3.79 & 2.50 & 11.36 & 1.60 & 4.55 & 6.15 & 4.37 \\
\hline Vietnam & 1.00 & 0.83 & 5.00 & 5.00 & 1.60 & 1.00 & 2.60 & 1.85 \\
\hline ASEAN & 24.00 & 20.00 & & & 16.00 & 24.00 & 40.00 & 28.41 \\
\hline ASEAN+3 & 120.00 & 100.00 & & & 20.80 & 120.00 & 140.80 & 100.00 \\
\hline
\end{tabular}

Source: Capannelli (2011a, 2011b).

initiatives, and agreements. The second variable is the potential for the successful integration of intra-regional trade activity to adopt a multilateral approach to regional economic growth based on key economic indicators, is assessed. Both variables were carefully analyzed and assessed. Similar studies by Capanelli (2011a, 2011b), Chin (2012, 2014) and Kabir and Salim (2014) have been conducted based on innovative economic integration techniques and the complex barriers confronted by ASEAN seeking regional economic cooperation. Importantly, this study distinguishes itself from other studies by utilizing the most recent trending data to provide updated findings. Such a comprehensive review of these two macro-economic variables that emphasize themes across data sets and 
other applicable data is the basis of this thematic analysis.

The coding to unlock the findings of this analysis was generated using NVivo qualitative data analysis software. This coding process developed an audit trail (codebook) in support of current comprehensive findings. Themes and patterns were identified using thematic analysis (a 6-phase data review process) where phase 1 consists of gaining familiarization with the data. Phase 2 consists of generating initial descriptive codes based on the deconstruction of the target data. Phase 3 consists of developing a thematic framework capturing core categories based on phase 2 codes and sub-codes in order to establish themes and context related to the aims of this study. Phase 4 consists of reviewing themes and synthesizing data to execute phase 5 which is the defining of themes and eventually phase 6 which produces the findings found in this study.

Thematic analysis methodology was employed for this study because it was the most relevant and appropriate method. Willig (2014) and Jones (2016) described thematic analysis as primarily a qualitative process of identifying themes and patterns in data that capture meaning relevant to the overarching incipient question under exploration. This particular research involved using recognized data themes to determine relevant meaning, findings, and conclusions. Table 2 portrays some of the core categories established through thematic analysis.
Table 2. Thematic framework core categories

1. Economic Performance Indicators

2. Comprehensive Investment Initiatives

3. Economic Data Sets

4. Regional Trade Initiatives

Liberalization of Capital Markets

5. Regional Policy Integration

To further enhance the thematic findings of this study a relational data model was developed using Microsoft Excel to create a range of relationships that correspond to the themes and patterns identified via NVivo as demonstrated in the indicative graphs and charts illustrated throughout this study. Such relationships between data were transcribed as a pivot table that functions similar to a database providing an insightful correlation of findings identified using NVivo and thematic analysis. It is this process that lends strong confidence in the findings of this study as the data from the newly produced pivot table using countries as the common relationship captures Foreign Direct Investment (FDI), Chiang Mai Initiative (CMI), Asian Bond Market Initiative (ABMI), Foreign Exchange Reserves (FER), Gross Domestic Product (GDP), ASEAN-SITS (Statistics on International Trade in Services), and other related regional data via this data model.

\section{The ABMI: Increasing Regional Financial Solidarity}

Adding to the collective economic tool kit of strategies, the ABMI offers stable regional investment vehicles that 
foster an increased regionalist approach to economic stability (Capannelli, 2011a, 2011b). As a tool developed by the region's central bankers, the ABMI uses only local currencies, thereby recycling local investments back into the Southeast Asian regional market. In the past, the unwitting employment of the U.S. dollar, euro, or yen produced everything from uncertainty to disaster. The purpose of establishing the ABMI is to diversify financial sourcing to counter the overdependence of Asian economies on commercial banking for domestic financing (Bhattacharyay, 2012).

This bond initiative was developed because the underdeveloped bond market exposed a lack of needed financial intermediaries such as insurance companies, retirement pension funds, and reliable and credible credit rating platforms for Asian companies (CalvoPardo, Freund, \& Ornelas, 2011). Similar to the CMI, developing the ABMI was critical to facilitate regional financial and economic integration to withstand any global crisis. Establishing effective policy coupled with massive Asian financial resources provided the foundation for developing region-backed bonds.

In 2009, USD 46 million of FDI flowed into the ASEAN region (ASEAN Secretariat, 2012, 2013b; Masron \& Nor, 2012). This welcome influx of foreign investment was a result of the solid foundation and doorway created by the ABMI. In 2010, the infusion of FDI into the ASEAN region rose to USD 108 million (ASEAN Secretariat, 2013b; Masron \&
Nor, 2012). By 2012, ASEAN's total FDI reached USD 117 million and approximately 75\% (USD 87,840,000) originated outside the Southeast Asian region (ASEAN Secretariat, 2012, 2013b). Although it was initially welcome, this exorbitant amount of FDI was also worrisome, as the non-Asian FDI outweighs intra-Asian investments by too much. Economists warned that this situation underscores Southeast Asia's financial dependency on external funds and its exposure to the vulnerability of North American and European Union markets.

Historically, these non-Asian markets would have been highly rated and prized, but after the U.S.-precipitated global recession in 2008-2009, the markets were noted to be indisputably fragile (Das, 2012; Erkens et al., 2012; Reinhart \& Rogoff, 2013). The CMI and the ABMI were established because of this fragility (Capannelli, 2011a, 2011b; Chin, 2012, 2014). Since this period, more regional integration efforts have been underway to attract external FDI in the form of publicprivate partnerships (PPPs) that can support diversified growth of the financial infrastructure while transferring risk to external investors.

Figure 1 depicts ASEAN's FDI from 1995 to 2016. In addition to the actual ASEAN FDI graph, the linear trend estimation portrays a regression analysis by calculating a straight line based on the actual FDI values from 1995 to 2016 and then forecasting them through 2020. The fidelity of this calculation is represented as 
$R^{2}=.7477$, which portrays an accuracy measurement of the trend line that is the quality of the trend prediction. Exponential growth is portrayed as a consistent rate of growth over a period of time, which in this case is until 2020. As shown in Figure 1, the inward FDI outlook for ASEAN appears positive over time.

\section{Figure 1. Inward FDI in ASEAN from 1995 to 2016; the estimated linear trend through 2020 and exponential growth through 2020}

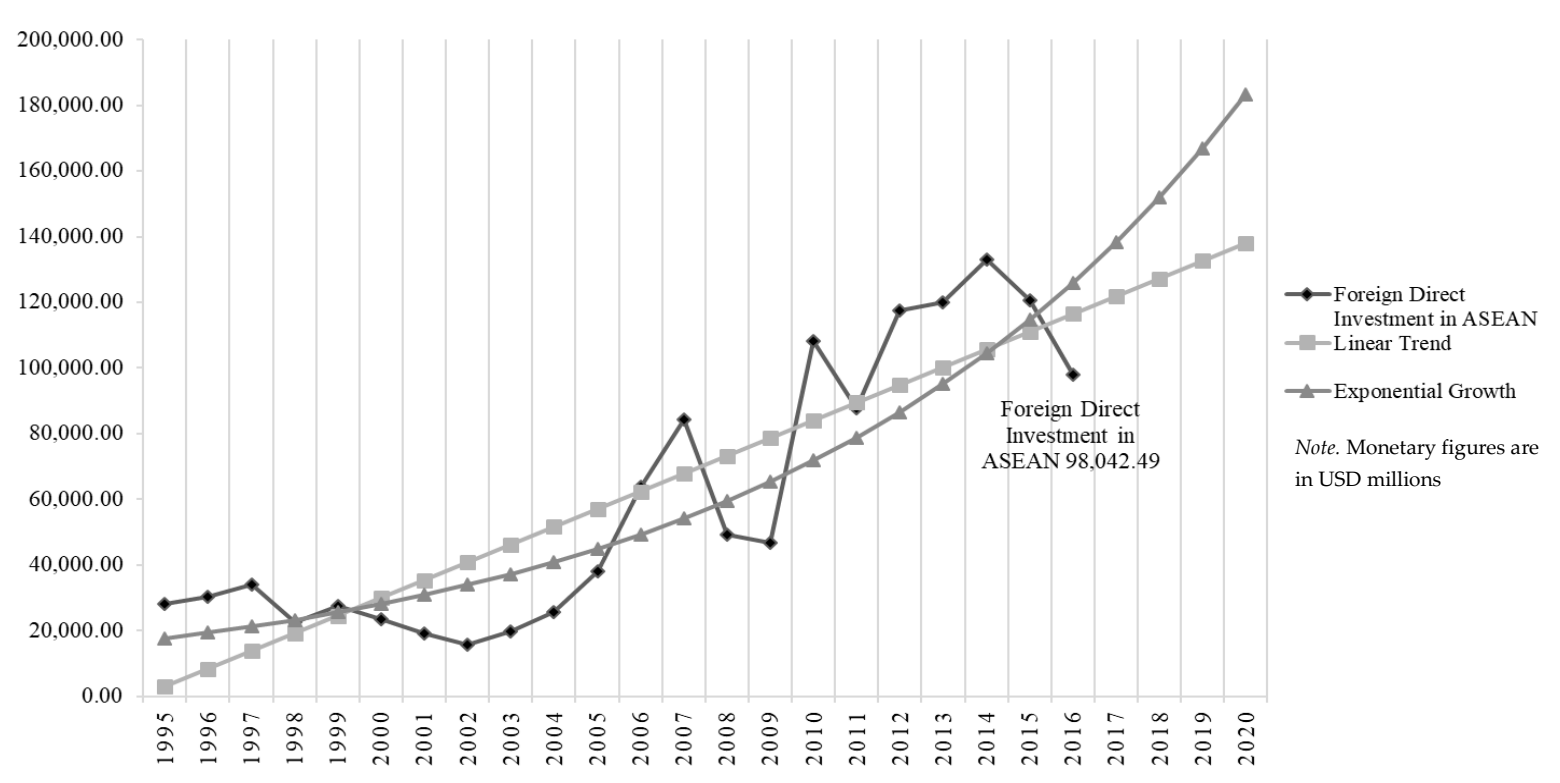

Sources: ASEAN Secretariat (2007, 2013, 2017); ASEANstats (2017); United Nations

Conference on Trade and Development (2017)

The ASEAN member states have shown resilience, elasticity, and forwardlooking ingenuity following two decades of financial turmoil. FDI declined in 2016, but overall the region attracted 3.4 times more investment than the 1995 peak (ASEAN Secretariat, 2017). The cohesive resilience among multiple nations justifies regional economic integration to tailor investments focusing on cross-border financial transactions amid efforts to reinforce intra-ASEAN trade, thereby fostering a regional development environment. The argument against this intraregional approach is that increasing capital mobility might cause cross-border financial contamination from neighboring countries. Therefore, diversity must be the focus of integration.

If a diversity model is properly implemented, economic integration in Asia has an excellent opportunity to fuel the ASEAN Economic Community, especially considering this region holds the majority of the world's foreign exchange reserves. Figure 2 displays the countries with the highest currency composition of official foreign exchange reserves in the world; notably, China has reserves over USD 3 trillion and Japan has reserves over USD 1 trillion (World Bank, 2018). As they are far exceeding debt requirements, countries in Asia are looking to reinvest these reserves through 
intraregional transactions that yield high returns and foster regionalist protections.

Other financial indicators that show ASEAN as a good candidate for implementing regional economic protection measures besides maintaining extremely large foreign exchange reserves in Asia are templating regional economic successes found throughout the region.
Mirroring the lessons learned in highly industrialized countries such as Singapore and Malaysia provide even more intraASEAN successes. Developing countries such as CLMV serve as ideal candidates to prosper from income distribution, liberalization of regional labor, liberalization of trade, and infrastructure development.

Figure 2. Global ranking of foreign exchange reserves 2017

Total reserves includes gold, current USD

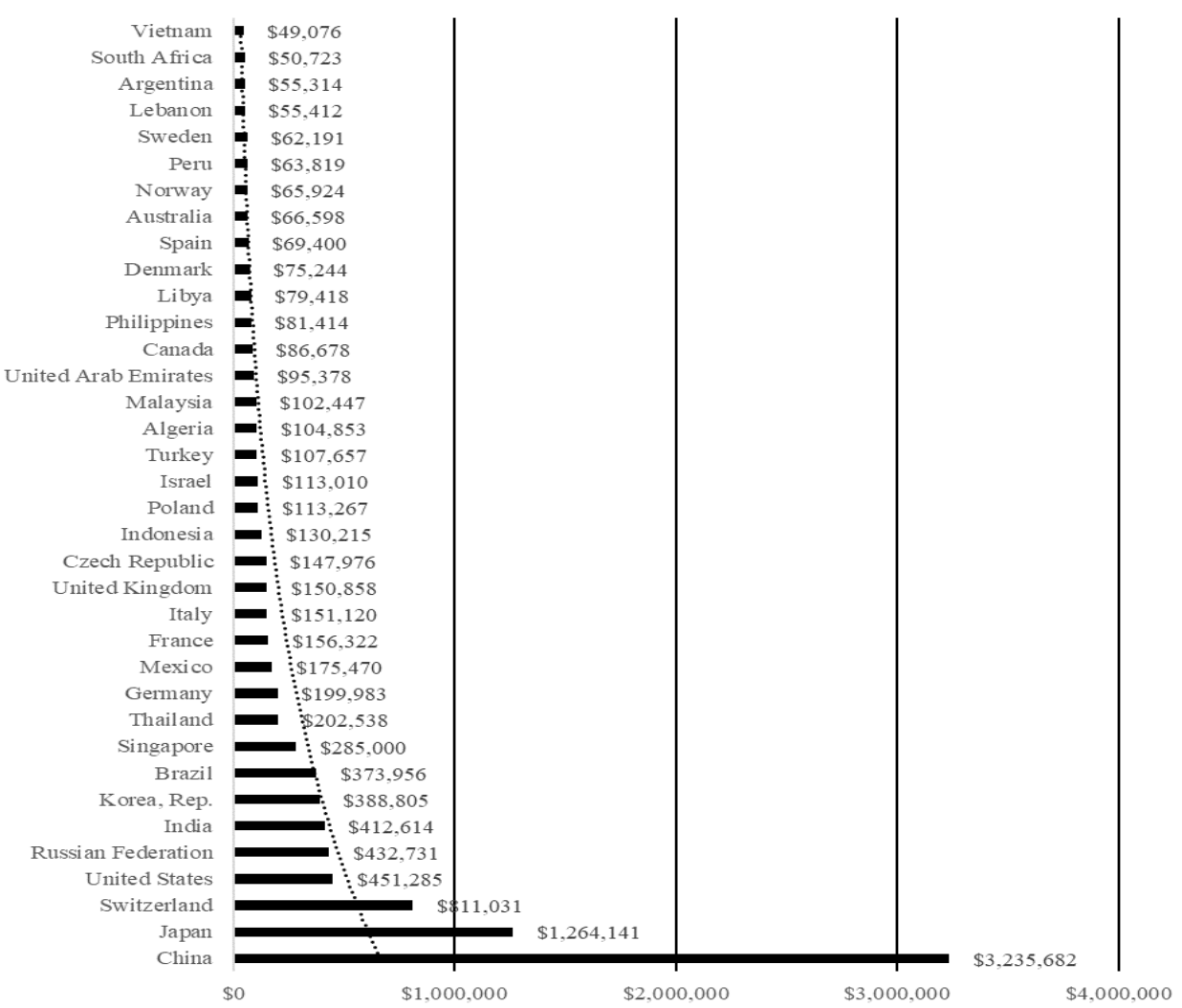

Note. Monetary figures are USD billions

Source: World Bank (2018).

If fully implemented to counter future crises, ASEAN+3 (China, Japan, and South Korea) could create the world's largest free-trade area, thereby potentially changing the future global economy (Calvo-Pardo et al., 2011; Petri, Plummer, \& Zhai, 2012).
The potential scope of this project can be visualized by studying the combined Southeast Asian regional gross domestic product (GDP) of USD 2.9 trillion projected for 2018, with real economic growth of about 5.1\% (ASEAN Secretariat, 2017; Asian Development 
Bank, 2017). It is widely forecasted that the rate of economic growth in ASEAN is poised to increase to $5.4 \%$ by 2023 based on strong economic spending in the region (International Monetary Fund, 2018). This trend shows that ASEAN is one of the world's fastest growing regional economies, with Cambodia, Laos, and Myanmar leading the Southeast Asia region for the foreseeable future while the
Philippines and Vietnam are expected to lead economic growth among the ASEAN5 (Indonesia, Malaysia, Philippines, Thailand, and Vietnam; Organisation for Economic Co-operation and Development [OECD], 2018). Figure 3 depicts the real GDP growth by annual percentage change for Southeast Asia and projected trends through 2020 for Southeast Asia.

Figure 3. ASEAN's regional real gross domestic product growth by annual percentage change from 2008 to 2017 and exponential growth through 2020

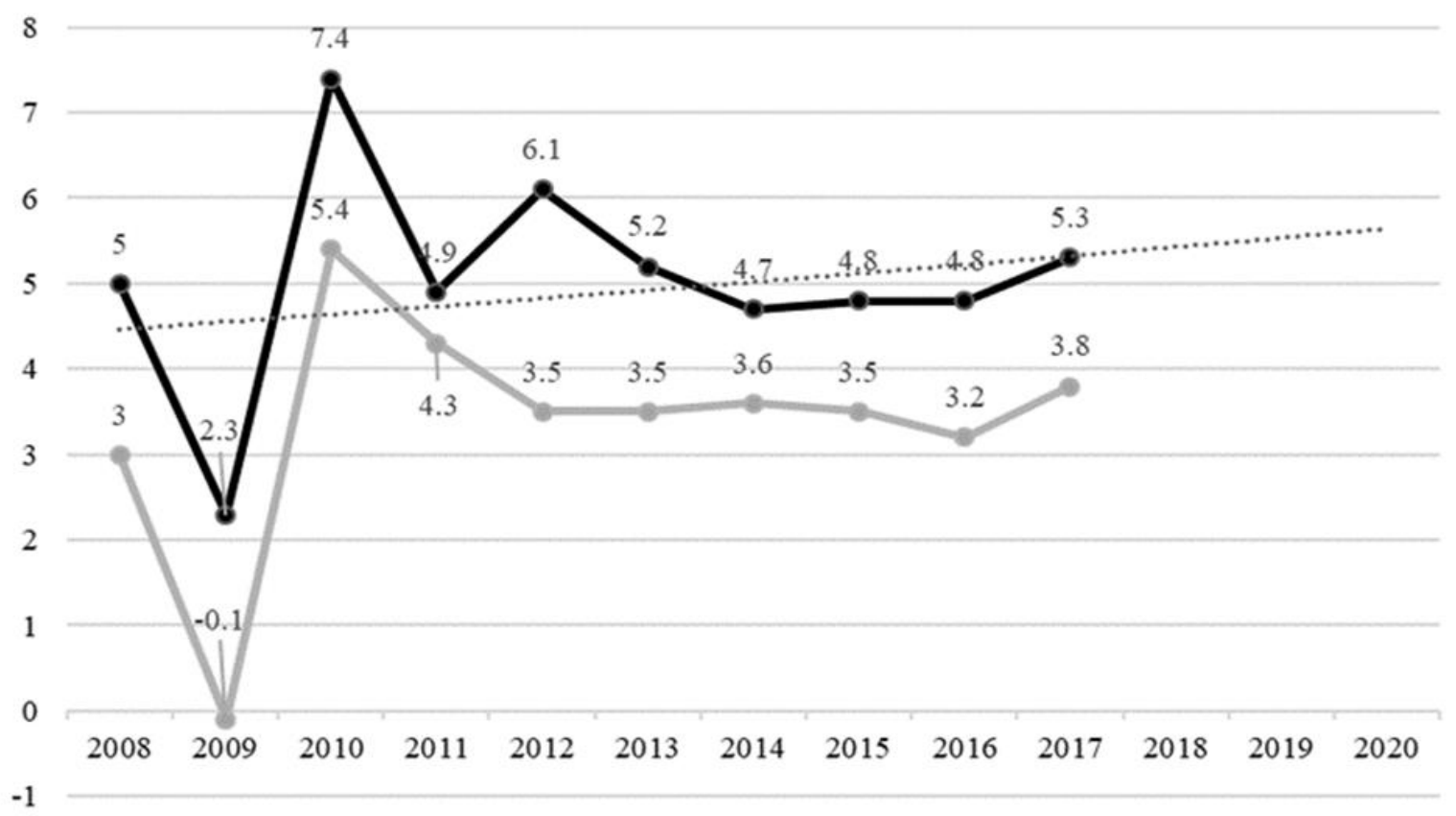

Southeast Asia Region $\quad$ World $\quad \cdots \cdots \cdot . .$. Exponential Growth (Southeast Asia)

Source: International Monetary Fund (2018)

Including the neighboring economies of China, Japan, and South Korea with ASEAN nations' regional GDP values profoundly alters the character of any future global financial crises. Historically, the devastating financial/economic crises were precipitated by burdensome financial ties with Europe and the United States, but a more financially protected ASEAN may have the best opportunity to implement a successful economic community. Key factors for this prediction include elevated foreign exchange reserves, regional trust funds, expanding regional bond markets, a solid market-driven economy, and the capability to integrate goods and trade via more streamlined trade policies, 
cooperation, and digital collaboration. All these factors reduce tariffs and comply with the ASEAN Trade in Goods Agreement in support of the ASEAN Single Window (ASW).

\section{ASEAN Single Window: A Trade Facilitation Catalyst}

In a specific effort to facilitate economic growth and competitiveness within the boundaries of ASEAN, this article also explores the ASW initiative that seeks to exponentially expedite trade facilitation, both regionally and internationally. The ASW is primarily based on Singapore's successful National Single Window (NSW), TradeNet, implemented in 1989. Figure 4 demonstrates the efficiency behind the NSW based on a digitized network for the electronic submission of customs documents, electronic payments, and government and business collaboration to become a competitive regional and global supply chain player to increase efficient trade flows. 1989. Figure 4 demonstrates the efficiency behind the NSW based on a digitized network for the electronic submission of customs documents, electronic payments, and government and business collaboration to become a competitive regional and global supply chain player to increase efficient trade flows.

Figure 4. Sample efficiency of the National Single Window process

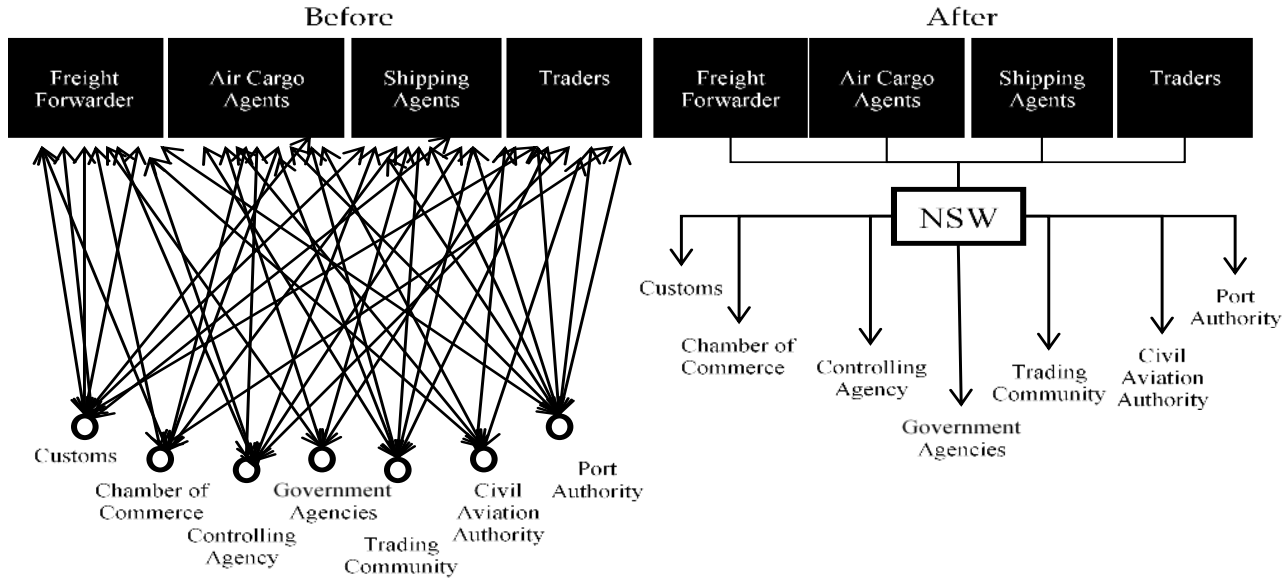

Source: adapted from CrimsonLogic (2010); Jones (2016)

The ASW is an environment in which 10 NSWs of individual ASEAN member countries collaborate with the private sector to design, operate, maintain, manage, finance, and integrate infrastructure projects in support of the world's first digitally integrated regional trade facilitation platform (Chia, 2013; Japan Association for Simplification of
International Trade Procedures, 2012; Jones, 2016; Kabir \& Salim, 2014; Neufeld, 2014). The ASW is a critical success factor for the regional integration of trade and services supported by multilateral tariff elimination, the harmonization of best business practices, and a common information and communication technologies infrastructure aimed at 
augmenting digital connectivity, business capacity, and the free flow of goods in the global supply chain. Key economic elements funding the ASW are FDI, composition of official foreign exchange reserves, and GDP. One key factor is the implementation of nontariff barriers designed to overcome trade barriers such as licensing and excessive cargo fees to better facilitate regional economic stability. Table 3 identifies the initial trade facilitation goals for ASEAN that will create and capture economic value through regional collaboration.

Table 3. Initial ASEAN Single Window Goals

1. Reduce the number of documents required to import and export among the ASEAN Member States

2. Reasonably reduce the physical inspection rate of goods

3. Complete the full roll out of the NSW project by 2018 (excluding Cambodia, Laos, and Myanmar)

4. Sign protocol supporting the ASEAN Customs Transit System, eliminate double taxation, and eliminate nontariff barriers against import and export goods (liberalization of regional transportation)

5. Fully implement the National Trade Repositories and the ASEAN Trade Repository

6. Substantially restructure business processes for enhanced streamlining and simplification

7. Accelerate standardization of data requirements and data exchanges to facilitate trade across regional borders; establish technical integration standards

8. Establish ASW technical working groups to facilitate regional information processing and sharing

9. Harmonize capital flow for import and export of cross border goods (standardized electronic payments)

10. Develop regional cooperation in infrastructure development to promote electronic commerce and transactions that provide the foundation for enhanced free trade agreements with other countries outside ASEAN

11. Increase global supply competitiveness, narrow the regional development gap, and foster financial stability against another financial crisis

Source: Intal, Dionisius, \& Fukunaga (2012)

Figure 5 portrays a simplified view of redundant connectivity via each ASEAN Member State's NSW infrastructure. The implied requirement to facilitate this digitized economic approach to regionalization is a robust and collaborative infrastructure along with harmonized formatting of shared data to mitigate cross-border challenges and increase intra-ASEAN trade growth
(Jones, 2016). The live exchange of harmonized data such as a certificate of origin when digitized is for use in completing the electronic ASEAN Trade in Goods Agreement Form D that aligns with collaborative regional policy requirements to identify preferential tariff treatment.

This digital integration across regional customs authorities is destined to 
significantly minimize hard-copy transactions and enhance business process and transaction management, along with

other optimization opportunities based on supportive regional policies.

Figure 5. ASEAN single window system engineering conceptual design for the electronic transmission of harmonized data

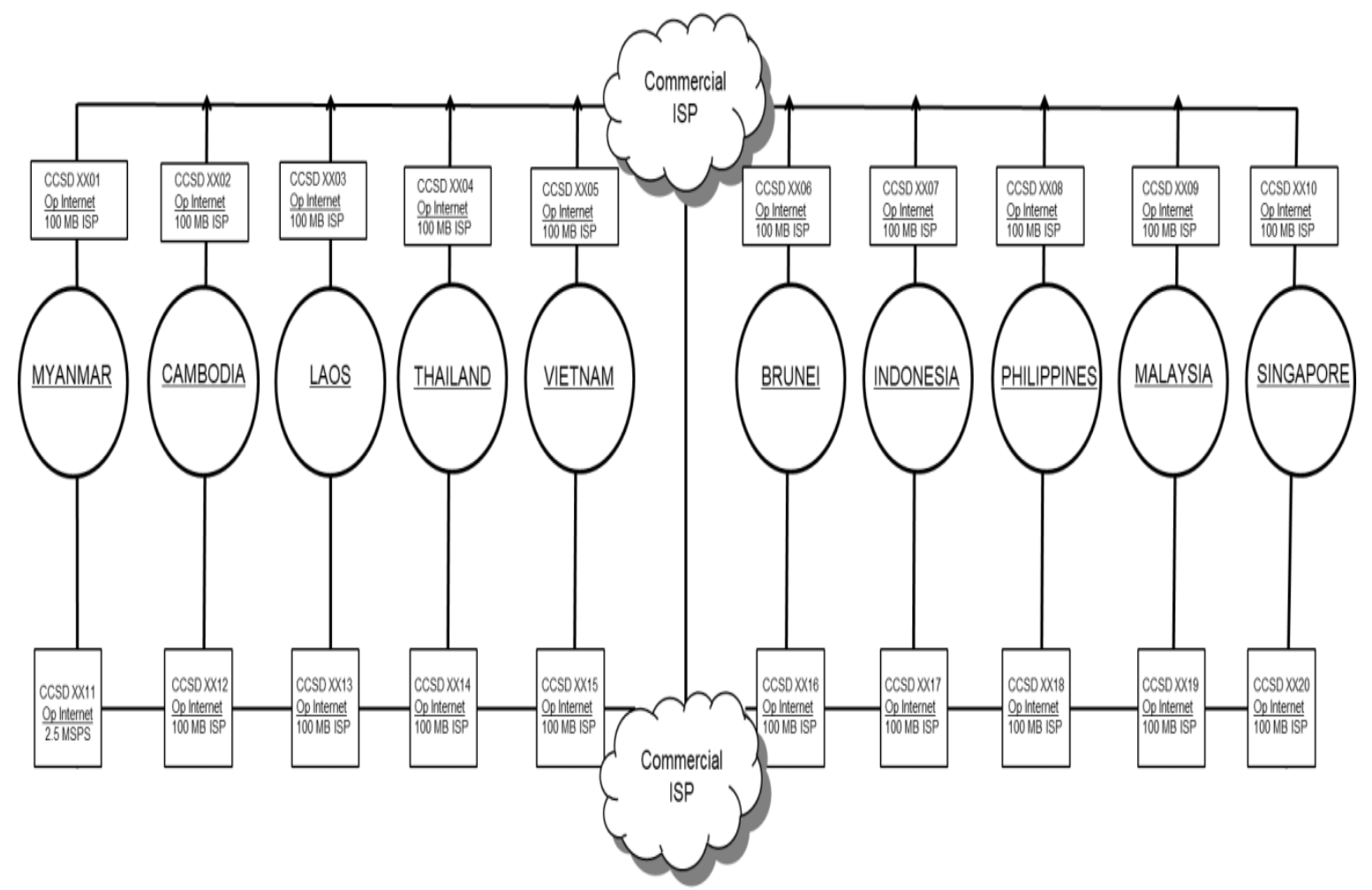

Source: Jones (2016)

These regional infrastructure integration policies will enhance communication, financial transactions, and supply chain risk management specifically in Laos, Myanmar, Indonesia, and Cambodia who currently have the lowest levels of Internet use in the region (OECD, 2018). Such techniques are key to reducing the digital divide among ASEAN member states, facilitating e-commerce growth, and increasing individual information and communication technologies skills.
The overarching goal of the ASW environment is to support a regional single market and production base with five core elements: (a) free flow of goods, (b) free flow of services, (c) free flow of investment, (d) free flow of capital, and (e) free flow of skilled labor (Chia, 2013; Japan Association for Simplification of International Trade Procedures, 2012; Jones, 2016; Kabir \& Salim, 2014). Another critical aspect of regionalism is collaboration and cooperation through tariff liberalization. As of January 2010, Brunei Darussalam, Indonesia, Malaysia, the Philippines, Singapore, and Thailand 
(ASEAN-6) eliminated intra-ASEAN import duties on $99.86 \%$ of tariff lines. CLMV senior leaders reduced their import duties between $0 \%$ and $5 \%$ on $98.86 \%$ of their tariff lines (ASEAN Secretariat, 2012; Hwang \& Lee, 2015; Petri et al., 2012). Progress across the region remains disparate due to differing national capabilities, despite striving for the same end state.

\section{Conceptual Framework: Collaborative Infrastructure and Policy Growth}

Constructing an ASW was, and still is, a sophisticated and complex project involving intricate computer engineering and high-level financial instruments. Having implemented the world's first digital collaborative trade facilitation system for Singapore in 1989 (CrimsonLogic, 2010) based on the principle of a PPP facilitates a risk transfer of financial debt in exchange for long-term corporate profits. Such a risk gap concept is preferred where economic conditions are fragile, although conceptualized integration must be achieved to create economic stability and stimulate future growth. Therefore, many ASEAN member states have turned to such best practices as establishing NSWs (trade facilitation systems) to develop similar techniques and procedures relative to each ASEAN nation.

The key assumption is that government-to-business and business-togovernment are perhaps the most relevant instruments for overcoming known financial, technological, economic, trade, and regulatory barriers related to implementing national trade facilitation systems, which is a government-tobusiness practice that Singapore was able to establish using a design, build, operate, and maintain model (Jones, 2016). Therefore, PPPs are considered a critical principle for attaining the ASW objective, especially for the CLMV nations.

As consumer purchasing power increases in line with regional economic growth, the result is an increase in jobs, living wages, standard of living, and quality health care options. But key to the success of various branches of regional integration is constructing solid policy agreements that hold intact the central focus areas and thematic engagements to overcome regional challenges, and strengthen capacity (OECD, 2018). Such steadfast willingness to standardize complex regional policies is a prime indicator of potential success.

In its simplest form, regional policy integration is a systems approach to planning. The interdependencies of the integrating focus areas, which include financial, economic, infrastructure connectivity, trade, and regional policy integration, infer that a change in one of the risk factors may have a serious effect on at least one of the other risk factors (Hartono, Sulistyo, Praftiwi, \& Hasmoro, 2014; Jones, 2016; McCann, 2013; Project Management Institute, 2013; Sebestyén \& Tóth, 2014; Zhang \& Fan, 2014). Therefore, even minimal changes can lead to economic disruptions (OECD, 2018). It is therefore imperative that a comprehensively regulated digital 
economy tying collaborative national infrastructures together demands a strategic and dynamic outlook, as demonstrated in Figure 6. With the regional focus areas of economic integration including a digital single market, financial integration, policy integration, and infrastructure connectivity listed in Figure 6, integrating to achieve equitable economic growth based on multitrack efforts includes participating in other multilateral free trade agreements in the Asia Pacific region that are also emerging. One of these is the Regional Comprehensive Economic Partnership (RCEP), which encompasses Australia, Brunei, Cambodia, China, India, Indonesia, Japan, Laos, Malaysia, Myanmar, New Zealand, the Philippines, Singapore, South Korea, Thailand, and Vietnam. The United States, under the Trump presidency, has disengaged from the Trans Pacific Partnership (TPP), which provides greater opportunity to create the Comprehensive and Progressive Agreement for Trans Pacific Partnership (CPTPP), a modified version of the original TPP.

Despite some changes in partnership, the digitized ASW, ASEAN Free Trade Area, RCEP, and CPTTP continue to progress. If ratified and implemented, the CPTPP economic model will represent approximately $13.5 \%$ of global GDP or USD 147 billion in global income gains (Goodman, 2018; Ji, Rana, Chia, \& Li, 2018) and expands liberalizing trade with other participating countries in the Pacific region such as Australia, Canada, and Japan. This expansion will significantly improve market access for emerging market countries such as CLMV. Thus, emerging market countries should reap the new benefits and stabilize economic equity in the region with more fair market access based on projected macroeconomic effects (Ji et al., 2018). Through an increase in regional opportunities, the RCEP represented approximately $31.4 \%$ of global GDP in 2016, or USD 23.8 trillion, and converging these aforementioned agreements into a Free Trade Area of the Asia Pacific with other regional partners represented 59.7\% of global GDP in 2016 or USD 45.1 trillion (Ji et al., 2018). Although the United States has disengaged from participating in multilateral free trade agreements such as the TPP thereby lowering initial economic cooperation predictions, the Asia Pacific block of nations continue to support multilateralism and regional cross-border trade. The ability to participate in the ASW and other free trade agreements widens the trading bloc and fundamentally supports the theory of regionalism as participating in multiple multilateral trade agreements and offering more economic opportunities while minimizing economic risk (OECD, 2018).

Data from 2010 shows a pattern of imbalance exists in intra-ASEAN import and export trade in services (see Tables 4 and 5). Despite hopes for quicker panregional trade equity, ASEAN import and export trade data from 2016 showed only marginal overall growth, with the longstanding gaps between the different nations remaining constant. This is also 
true for intra-ASEAN import and export trade in goods.

\section{Figure 6. Venn diagram of integrated thematic focus areas}

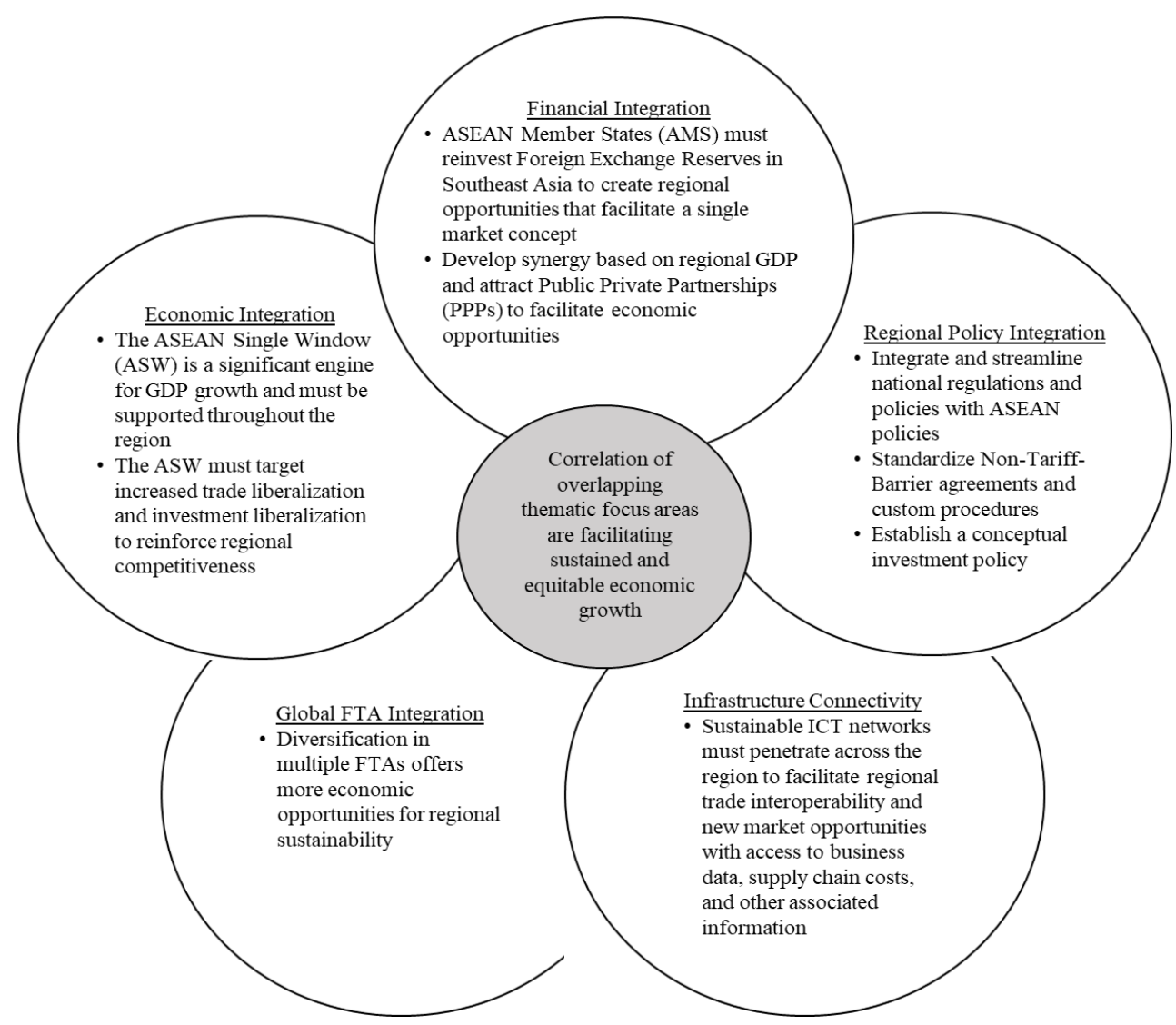

Therefore, similar to the CMI and ABMI economic tools established to support investments internally in the ASEAN region, regional free trade agreements with common access benefits such as nontariff barriers are anticipated to even the disparity via updated integration policies and infrastructures. Good trade agreements are necessary and work.Before the TPP was modified to the CPTPP, it was projected to be the largest regional trade agreement (Petri \& Plummer, 2016). Regardless of the modifications to the CPTPP, gains are projected to be significant upon ratification.
Table 4. 2010 and 2016 ASEAN import trade in services by reporting countries in USD million

\begin{tabular}{lll}
\hline \multicolumn{1}{c}{ Country } & \multicolumn{1}{c}{$\begin{array}{c}\text { Sum of } 2010 \\
\text { imports }\end{array}$} & \multicolumn{1}{c}{$\begin{array}{c}\text { Sum of } 2016 \\
\text { imports }\end{array}$} \\
\hline $\begin{array}{l}\text { Brunei } \\
\text { Darussalam }\end{array}$ & $\$ 1,267.30$ & $\$ 1,644.60$ \\
Cambodia & $\$ 980.24$ & $\$ 1,951.65$ \\
Indonesia & $\$ 26,460.99$ & $\$ 30,521.33$ \\
Laos & $\$ 263.12$ & $\$ 619.17$ \\
Malaysia & $\$ 31,833.54$ & $\$ 39,872.59$ \\
Myanmar & $\$ 729.20$ & $\$ 2,899.50$ \\
Philippines & $\$ 12,017.00$ & $\$ 24,232.73$ \\
Singapore & $\$ 101,212.69$ & $\$ 155,585.88$ \\
Thailand & $\$ 41,333.32$ & $\$ 42,778.43$ \\
Vietnam & $\$ 9,857.00$ & $\$ 16,477.00$ \\
Grand total & $\$ 225,954.40$ & $\$ 316,582.89$ \\
\hline
\end{tabular}


Table 5. 2010 and 2016 ASEAN export trade in services by reporting countries in USD million

\begin{tabular}{|c|c|c|}
\hline Country & $\begin{array}{c}\text { Sum of } 2010 \\
\text { exports }\end{array}$ & $\begin{array}{c}\text { Sum of } 2016 \\
\text { exports }\end{array}$ \\
\hline $\begin{array}{l}\text { Brunei } \\
\text { Darussalam }\end{array}$ & $\$ 460.50$ & $\$ 530.50$ \\
\hline Cambodia & $\$ 2,028.46$ & $\$ 4,458.29$ \\
\hline Indonesia & $\$ 16,670.51$ & $\$ 23,478.20$ \\
\hline Laos & $\$ 511.00$ & $\$ 830.97$ \\
\hline Malaysia & $\$ 33,822.79$ & $\$ 35,270.61$ \\
\hline Myanmar & $\$ 350.70$ & $\$ 3,779.40$ \\
\hline Philippines & $\$ 17,782.00$ & $\$ 31,357.24$ \\
\hline Singapore & $\$ 100,832.20$ & $\$ 149,647.12$ \\
\hline Thailand & $\$ 34,339.83$ & $\$ 65,244.58$ \\
\hline Vietnam & $\$ 7,417.00$ & $\$ 12,228.00$ \\
\hline Grand total & $\$ 214,214.98$ & $\$ 326,824.92$ \\
\hline
\end{tabular}

Source: ASEANstats (2017)

Although economic disparity decidedly exists across the 10 ASEAN member states, continued multination collaboration and integration will gradually reduce the most severe disparities over time. Understandably, achieving pan-ASEAN economic parity remains a complex and challenging endeavor. However, an overall unified ASEAN Economic Community will, according to reliable data signs, increase in strength and serve the region with effective strategies for collective economic prosperity otherwise referred to as economic regionalism.

\section{Conclusion}

From analyzing the most pertinent data sets tracking the machinations of ASEAN's single market model, regionalism, it appears it is proving to be a feasible, viable, visionary three-pronged plan successfully establishing: a) a protective financial bulwark against both unexpected and/or targeted financial interruptions from non-Asian states, b) financial instruments to protect itself from internal financial difficulties and, c) a much more robust and integrated regional economy. Naturally, the more integrated the trading platforms become, the increasingly greater and more successful regionalism becomes. These platforms include multilateral intra- and extraASEAN collaborative trade relationships, the ASW's sophisticated digital trade platform, expedited payment platforms for business-government/governmentbusiness transactions and integrated governmental infrastructures. These are the gears, nuts and bolts that engineer the single market regional model and have to date manifested tangible, recordable increased regional profitability and heightened financial security and resiliency. The growing success of the regionalism model makes it more trusted and valuable as a trading partner and attractive to non-Asian global traders and investors. However, the model has not yet had to be tested by a crisis such as the 1997 Asian Financial Crisis or the North American 2007/2008 Financial Crisis. Until it survives a storm of those magnitudes, the model is not a proven risk-free entity. But, for now, the trajectory for this model is on a positive course delivering greater fiscal safety and resiliency as well as increased profitability for the ASEAN single market region. This portfolio of regional economic integration activities and growth initiatives was demonstrated in figure 1 (FDI) linear inward trends, 
figure 2 (FER) Asian reserves, figure 3 (GDP) regional annual growth, table $4 \& 5$ (trade) annual growth in services and goods signifying ASEAN's value chain approach to economic regionalism.

\section{About the Author}

Craig A. M. Jones is an Adjunct Professor at the Graduate School of Business and Management, Argosy University, Honolulu, Hawaii. He received a doctorate of business administration in international business, summa cum laude and wrote a dissertation in which he addressed business strategies concerning import and export trade facilitation in Southeast Asia as a partnership between ASEAN and the private business sector to bring about strategic economic change. He received his master of business administration in international business, magna cum laude, and a bachelor of arts in French language and literature.

\section{References}

ASEAN Secretariat. (2007). ASEAN investment report 2006. Jakarta, Indonesia.

ASEAN Secretariat. (2012). ASEAN Economic Community (AEC) handbook for business 2012. Jakarta, Indonesia.

ASEAN Secretariat. (2013a). ASEAN Economic Community (AEC) chartbook 2012. Jakarta, Indonesia.
ASEAN Secretariat. (2013b). ASEAN investment report 2012. Jakarta, Indonesia.

ASEAN Secretariat. (2017). ASEAN investment report 2017. Jakarta, Indonesia.

ASEANstats. (2017). ASEANstats database. Jakarta, Indonesia: ASEAN Secretariat.

Asian Development Bank. (2017). Asian development outlook 2017 update: Sustaining development through public-private partnership. Asian Development Outlook, 242.

Bhattacharyay, B. N. (2012). Seamless sustainable transport connectivity in Asia and the Pacific: prospects and challenges. International Economics and Economic Policy, 9(2), 147-189.

Calvo-Pardo, H., Freund, C., \& Ornelas, E. (2011). Cost and benefits of economic integration in Asia. In R. Barro \& J.-W. Lee (Eds.), The ASEAN free trade agreement: Impact on trade flows and external trade barriers (pp. 157-186). London, United Kingdom: Oxford University Press.

Capannelli, G. (2011a). Institutions for economic and financial integration in Asia: Trends and prospects. ADBI Working Paper Series, No. 308. http://hdl.handle.net/10419/53695

Capannelli, G. (2011b). Shaping Asia's institutional architecture for 
economic and financial integration:

Opinion leaders' views. International Economic Journal, 25, 593-616.

Chia, S. (2013). The ASEAN Economic Community: Progress, challenges, and prospects. ADBI Working Paper Series, No. 440.

Chin, G. (2014). Asian regionalism after the global financial crisis. In G. Capannelli \& M. Kawai (Eds.), The political economy of Asian regionalism (pp. 39-58). Tokyo, Japan: Springer.

Chin, G. (2012). Regionalism and economic globalization. $A D B I$ Working Paper 343.

CrimsonLogic. (2010). World's first trade facilitation system: TRADENET. Singapore.

Das, D. K. (2012). How did the Asian economy cope with the global financial crisis and recession? A revaluation and review. Asia Pacific Business Review, 18, 7-25.

Erkens, D. H., Hung, M., \& Matos, P. (2012). Corporate governance in the 2007-2008 financial crisis: Evidence from financial institutions worldwide. Journal of Corporate Finance, 18, 389-411.

Goodman, M. (2018). From TPP to CPTPP. Washington DC: Center for Strategic and International Studies.

Hartono, B., Sulistyo, S. R., Praftiwi, P. P., \& Hasmoro, D. (2014). Project risk: Theoretical concepts and stakeholders' perspectives. International Journal of Project Management, 32, 400-411.

Hwang, S., \& Lee, S. (2015). Regional economic integration and multinational firm strategies. Journal of International Trade $\mathcal{E}$ Economic Development, 24, 968-1013.

Intal, P., Dionisius, N., \& Fukunaga, Y. (2012). Mid-term review of the implementation of AEC Blueprint: Executive summary. Jakarta, Indonesia: Economic Research Institute for ASEAN and East Asia.

International Monetary Fund. (2018). World economic outlook: Real GDP growth. Washington DC.

Japan Association for Simplification of International Trade Procedures. (2012). ASEAN single window: Hearing survey in 2012. Tokyo, Japan.

Ji, X., Rana, P. B., Chia, W.-M., \& Li, C. T. (2018). Trade policy options for ASEAN countries and their regional dialogue partners: "Preference ordering" using CGE analysis. (Rajaratnam School of International Studies - Working Paper No. 308). Singapore: Nanyang Technological University.

Jones, C. (2016). Business strategies for ASEAN's Single Window in Southeast Asia (doctoral dissertation). Available at 
ProQuest Dissertations \& Theses. (UMI No. 10248949)

Kabir, S., \& Salim, R. A. (2014). Regional economic integration in ASEAN: How far will it go? Southeast Asian Economies, 31(2), 24.

Masron, T. A., \& Nor, E. (2012). FDI in ASEAN-8: Does institutional quality matter? Applied Economics Letters, 20, 186-189.

McCann, D. E. (2013). Managing changes in project scope: The role of the project constraints (doctoral dissertation). Available at ProQuest Dissertations \& Theses. (UMI No. 3568940)

Neufeld, N. (2014). Trade facilitation provisions in regional trade agreements: Traits and trends. Journal of International Commerce, Economics and Policy, 5, 145.

Organisation for Economic Co-operation and Development. (2018). Economic outlook for Southeast Asia, China, and India 2018: Fostering growth through digitalisation. Paris, France: OECD Publishing.

Petri, P., \& Plummer, M. (2016). The economic effects of the Trans-Pacific Partnership: New estimates (PIIE Working Paper Series WP 16-2). Washington, DC: Peterson Institute for International Economics.

Petri, P., Plummer, M. G., \& Zhai, F. (2012). ASEAN Economic
Community: A general equilibrium analysis. Asian Economic Journal, 26(2), 93-118.

Project Management Institute. (2013). A guide to the project management body of knowledge (PMBOK® guide) (5th ed.). Newtown Square, PA.

Reinhart, C. M., \& Rogoff, K. S. (2013). Banking crises: An equal opportunity menace. Journal of Banking \& Finance, 37, 4557-4573.

Sebestyén, Z., \& Tóth, T. (2014). A revised interpretation of risk in project management. Periodica Polytechnica Social and Management Sciences, 22, 119-128.

United Nations Conference on Trade and Development. (2017). Foreign direct investment: Inward and outward flows and stock, annual, 1970-2016. Geneva, Switzerland: UNCTADSTAT.

Willig, C. (2014). Interpretation and analysis. In U. Flick (Ed.), The SAGE handbook of qualitative data analysis (pp. 136-151). London, United Kingdom: SAGE.

World Bank. (2018). Total reserves (includes gold, current US\$). Washington DC.

Zhang, Y., \& Fan, Z.-P. (2014). An optimization method for selecting project risk response strategies. International Journal of Project Management, 32, 412-422. 